\title{
New directions in New Zealand local government
}

Commonwealth Journal of Local Governance

Special Issue March 2010:

Commonwealth Local Government Conference

Freeport, Bahamas, May 2009

http://epress.lib.uts.edu.au/ojs/index.php/cjlg

\section{Peter McKinlay}

Director, Local Government Centre

AUT University, Auckland

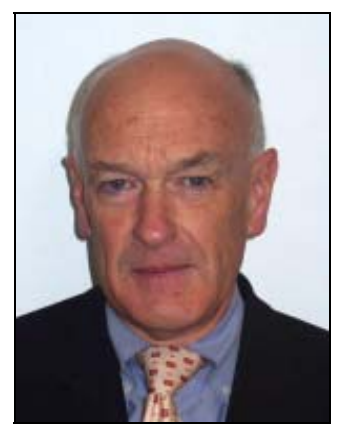

\section{Introduction}

The purpose of this paper is to provide a 'work in progress' report on some initiatives emerging from local government practice in New Zealand which should help us consider how we think about the role of local government in a world which is undergoing dramatic change. The starting point is work which the writer undertook with the support of Local Government New Zealand (the national association) and a number of New Zealand councils considering the 'proper role' of local government. The context is an ongoing public debate driven substantially by the New Zealand business community from a perspective that this 'proper role' should be restricted to the delivery of local public goods, narrowly defined. This has included argument that local governments themselves should be structured substantially to promote the efficient delivery of services generally within the now well understood prescriptions of the 'new public management'. One implication which the business sector in particular drew in looking at the workings of local government was that there should be economies of scale through further amalgamation of councils (the local government sector having been through a major amalgamation process in 1989 which eliminated a large number of special purpose authorities and reduced the number of territorial local authorities from more than 200 to 73). Debate continues, with the latest manifestation being the National Party led 
government's proposals for the restructuring of local government within the Auckland region, New Zealand's major metropolitan area. The initiatives discussed in this paper are partly a response, but more significantly a result of selected local authorities reflecting on the nature of their role, and the opportunities for being proactive in using their statutory privileges in ways that could produce benefits for their communities without any associated increase in the cost of local government itself.

\section{Background and legislative changes}

New Zealand local government, as already noted, underwent substantial restructuring in 1989. This involved amalgamating smaller local authorities and doing away with a number of special purpose bodies, and absorbing their functions into general-purpose territorial authorities. It was also a matter of attempting to improve both the efficiency of operation, and the transparency and accountability of individual councils. This included:

- Requiring local authorities to adopt accrual accounting, including preparing accounts in accordance with generally accepted accounting practice.

- Moving to a 'general manager' model of administration under which the council ceased to be the employer of all staff and instead had just one employee, its chief executive, who also had a statutory monopoly on advising the council itself (i.e. all other staff had to report through him/her).

Further changes took place during the 1990s designed primarily to improve local government accountability. These included statutory provisions to require prospective accountability - long-term financial and activity plans - and enhanced statutory obligations for public consultation. What had been largely missing in the changes in the late 1980s and throughout the 1990s was any substantive debate over the proper role and function of local government. This came to the fore at the beginning of this century when the then Labour-led central government responded to representations from the local government sector that local government legislation was badly out of date and urgently in need of revision. The Act at the time had been amended some three or four times a year over a period of around 30 years, with the result that it had become extremely difficult to find any coherent logic throughout its provisions. The Labour led government was also aware of developments internationally, especially in England, where the Local Government Act 2000 had introduced a power for local authorities to promote economic, environmental and social well-being. The New Zealand government saw this as an appropriate role for local government, especially as it was becoming more and more 
concerned with how to address problems of social dysfunction at a local level. It was also responsive to representations from local government that the existing legislation was extremely confused in terms of the powers conferred. There were some extraordinarily broad and unconstrained powers but also some remarkably narrow and restrictive provisions - reconciling the two competing approaches was becoming more and more difficult. Accordingly, the government decided to rewrite local government legislation and passed the Local Government Act 2002 which included some significant changes. Amongst those the government regarded as the most important were:

- Rewriting the statutory purpose of local government as to:

o Enable democratic local decision-making and action by, and on behalf of, communities; and

o Promote the social, economic, environmental, and cultural well-being of communities, in the present and for the future.

- Granting local authorities the power of general competence expressed as "for the purposes of performing its role, a local authority has full capacity to carry on or undertake any activity or business, do any act, or enter into any transaction" and for those purposes, "full rights, powers, and privileges" (Local Government Act 2002, 'Status and powers', Section 12).

One of the delightful ironies of the changes was that buried in the mess which was the previous Act was a power of general competence somewhat broader than the power in the new Act. This irony escaped a number of commentators, including much of the business community, which reacted with a measure of horror at what it thought was the unleashing of local government to undertake whatever activity it thought fit with the compulsory backing of ratepayers. The new Act triggered a number of different responses. The two most significant were:

- To heighten concern within the business community that local government had untrammelled powers which presented very real threats to the business community in particular, but the wider community as well, because of the potential to undertake a very wide range of activity with what the business community felt was insufficient public control. The immediate consequence was an intensification of the business community's representations that local government should be restricted to the core business of delivering local public goods, narrowly defined. 
- To encourage many local authorities, often for the first time, to consider how their activities promoted community well-being as opposed to the standard service delivery activities which for most of them had been their primary focus.

The business argument was very much focused on promoting efficiency as the business community saw it. This included further amalgamation on the basis that this would produce economies of scale, as well as that local authorities should be constrained in terms of the activities they could undertake.

\section{The local government sector response}

Although the then government had made it clear it had no appetite for further local government restructuring (amalgamation), the sector itself recognised that this was no assurance restructuring was off the agenda - governments change, especially in a polity such as New Zealand where elections take place once every three years. Accordingly, it decided it was timely to commission research looking at issues such as amalgamation and efficiency, in the hope of providing evidence which might support arguments against the risk of local government being subjected to further restructuring in the belief that 'bigger is better', or that local government should be tightly restricted in the activities it could undertake. This paper's author, in his consulting capacity, was commissioned to undertake the work. The resultant report (McKinlay Douglas Limited 2006) was a wideranging literature review of existing research on the role and efficiency of local government. The report's policy implications included:

- Of particular importance for the current debate in New Zealand is what the literature has to say about economies of scale as a rationale for local government amalgamation. In general, the research argues that larger local authorities tend to be less efficient than medium-sized or smaller authorities. More importantly, although achieving economies of scale matters, they do not provide a rationale for local government amalgamation.

- Changing understandings of the role and nature of local government, including the new statutory duty for New Zealand local authorities to promote community well-being, suggest that questions of structure need to be looked at not only in terms of efficiency but also in terms of what is consistent with enabling strong communities in ways which in turn feed through to improved social and economic outcomes. 
These findings were consistent with changes taking place internationally in understanding the potential of local government not just as a service deliverer, but as a critical element in the development of sustainable communities. They were not, however, determinative of the broader public debate about the proper role of local government. The argument that it should be restricted to local public goods was still very much alive and well as can be seen from the following extract from a major submission made to the recent New Zealand Rating Inquiry ${ }^{1}$ by the New Zealand Business Roundtable one of the country's leading business lobby groups:

\begin{abstract}
The distinct danger of adding to current rating tools is that new funding mechanisms are used to source additional revenue without clear understanding of the proper role of local government. There are already arguable cases where targeted rates (including development contributions) are not based on sound economic principles but are seen as additional revenue generating devices. The clear issue in respect to available funding mechanisms is that those who benefit from the services provided should pay in proportion to the benefits received from utilising those services. While there will always be an element of crosssubsidisation, as for some services it would be well nigh impossible to introduce effective user charges, the majority of services (many of which are funded out of general rates e.g. waste disposal) could be funded in this way (i.e. in proportion to benefits received).

(Submission 572, Local Government Rates Inquiry)
\end{abstract}

The same lobby group in a submission to the Royal Commission on the Governance of Auckland $^{2}$ argued that the proper role of local government should be confined to local regulation and to:
... facilitating the provision of goods and services that cannot be supplied efficiently through voluntary transactions by individuals, firms and not-for- profit organisations. Such activities involve the provision, funding, or both, of public goods and services. In broad terms, public goods cannot be produced by the private sector with known technology, except under contract. It is usually not possible to charge for them. National defence and street-lighting are commonly cited examples of public goods.

Applying that interpretation, two consequences would follow:

- Local government would not undertake any activity which could potentially be undertaken by others, either on a voluntary basis or through contract.

\footnotetext{
${ }^{1}$ The report of the inquiry, Funding Local Government (Report of the Local Government Rates Inquiry) is available at:

Hhttp://www.dia.govt.nz/diawebsite.nsf/wpg_URL/Agency-Independent-Inquiry-into-Local-

Government-Rates-Rates-Inquiry-Reports?OpenDocument

${ }^{2}$ Submission to the Royal Commission on Auckland Governance. See

Hhttp://www.nzbr.org.nz/submissions.asp?DocType=Submission\&offset=10
} 
- Local government activities would have a minimal impact on redistribution as between better off and less well off residents/ratepayers/areas within the district of any given council. The redistributive impact would be confined solely to those services where it was technically impossible to put in place an effective means of user charging.

Variants of this approach have been characteristic of discussions about the proper role of local government in most of the developed world during much of the latter part of the 20th century. It has been associated with the so-called 'new public management' approach which has focused on councils as efficient service deliverers and residents and ratepayers as 'customers'. In the United States it has seen an ongoing debate between the 'public choice' school who argue that the structural arrangements for local government should provide the opportunity for people to select that mix of taxes and services they prefer, and 'new consolidationists' who argue for a broader and more redistributive role for local government. At the risk of oversimplifying the argument, the 'public choice' argument is that people should only pay for what they get and get what they pay for, whilst the 'new consolidationists' argue that local government plays a crucial role in the building of inclusive societies, which necessarily involves a measure of redistribution to ensure that services are designed to meet need rather than restricted by individual ability to pay (but recognising that overall community ability and willingness to pay is an essential constraint). The latter approach comes much closer to treating local governments as being an expression of local democratic choice rather than simply service providers. Readers who want to see a more detailed discussion of these issues are referred to Lowery (2000).

The current situation, in most English-speaking developed countries, is one of continuing tension between a business perspective that local government should have a relatively restricted role focused on service delivery, and the competing view (usually reflected in the mandates which central governments provide for the local government sector) that local government has a broader role in promoting community well-being. In comparison with the narrow perspective, this is still a relatively new understanding but one which appears to be gathering ground. Much of this changing approach to thinking about local government was captured in the November 2008 report to the government of the Canadian province of New Brunswick of the Commissioner on the Future of Local 
Governance presented by Commissioner Jean-Guy Finn. In scoping the nature of local government, his report had this to say:

\begin{abstract}
The shape a local government takes is largely influenced by its two basic roles or functions, which are generally recognized and accepted as administration (of services) and representation (expression of people's wishes). The performance of a local government organization, consequently, should be measured mainly by its effectiveness in carrying out these two functions. Over time, and depending on the geographical context, either of these functions may be emphasized or receive more attention. It is fair to say that, lately, in New Brunswick as in most other areas of Canada, the primary role of local government institutions has been equated with the delivery of local services. Rather than stressing local government in relation to democracy, the tendency has been to defend it as an efficient agent for providing services.
\end{abstract}

However, it is important to realize that one function cannot be carried out at the exclusion of the other. Local institutions exist not only to provide certain services but also to represent the wishes of their residents. "Combining these roles suggests that local government exists to provide services in accordance with the needs and wishes of its local inhabitants" [Tindal, 1977, p. 3]. One of the justifications for local government, therefore, is that it serves as an instrument of democracy as well as a service delivery agency. (Finn 2008). [Emphases in the original].

The experience on the ground, in how local government actually delivers on the renewed emphasis on what can variously be described as local democracy or community wellbeing, is rather more mixed than changes in legislation and the wording of government reports might suggest. First, different countries have different administrative traditions. English local government, for example, is subject to a very great deal of top-down direction which extends to the way in which it implements the community well-being power. New Zealand local government, in contrast, receives very little direction from central government in terms of how it delivers on its community well-being role, but is subject to very prescriptive requirements about how it undertakes and reports its longterm planning activities, which in practice have acted to discourage innovation in many councils. Secondly, another factor limiting the extent to which local governments have changed emphasis is simply institutional inertia. In New Zealand, as an example, many councils saw the new role of promoting community well-being as an attempt to move them away from what they regarded as their traditional 'roads, rates and rubbish' functions to more of a social service role. A number of councils also feared that this was part of a government strategy of cost shifting to local government. As a result, and not surprisingly, what can be observed in most jurisdictions which have sought to change the emphasis of local government activity more towards local democracy/community wellbeing is that change is more in the nature of ad hoc local initiatives than any deliberate 
sector-wide strategy. Nonetheless, there is reason to believe that this ad hoc process could be more significant in its long-term implications than any attempt to put in place a deliberate strategy of change.

The balance of this paper looks at some international examples and then three potentially interrelated initiatives currently under way within individual New Zealand councils, and considers their potential to lead to a fundamentally different understanding of the role which local government can play in the lives of its citizens, not just in New Zealand but in other jurisdictions.

\section{International examples}

Local governments generally have long had the power to encourage innovative activity at a community level if they wish to do so. Normally this has been inhibited by concerns over capability, both within the local authorities themselves, and at the community level. As a consequence, it is only relatively recently that whole sectors have been adopting, or been required to adopt, strategies which emphasise developing community capability. One obvious strategy is the use of the local authority's procurement powers to purchase from a community-based third-party services which it wishes to deliver to its constituents. There have been occasional instances of this within most local authority jurisdictions with initiatives such as the establishment of trusts, independent of the local authority, but operating under contract to deliver cultural and recreational services, but these have tended by and large to stay within well-defined boundaries set by the local authority itself. There is evidence that the real gains from this approach come when the community- based third-party has the mandate and structure to grow its activities beyond the original confines of the local authority's own requirements. An early example from England is Greenwich Leisure Ltd, which has developed into a very successful employee-owned business contracting to a large number of local authorities.

In 1993 the London Borough of Greenwich was required to make very substantial budget cuts. One area in which it looked for savings was its leisure activities. The conventional approach would have been to cut back its investment in the management of leisure facilities. Instead the council decided to convert the leisure management activity into a separate business. The form chosen was an Industrial and Provident Society: a not-forprofit entity controlled by its employees with council support coming through its procurement policy - by purchasing leisure management services from the new entity. It 
commenced business operating seven leisure centres all on behalf of Greenwich Borough Council. It has grown to become one of the largest leisure management businesses in the United Kingdom, providing management services to a number of local authorities, operating more than 70 centres, employing in excess of 4000 staff and winning a number of national awards for service and quality. The council has benefited significantly as the success of Greenwich Leisure Ltd has underpinned the establishment of additional leisure centres within Greenwich, as well as the provision of a wider range of leisure services, and the business itself has become a significant employer.

As is the case with much of local government innovation in England, central government has recently determined that the development of what are referred to as social enterprises within communities should be encouraged. It is effectively directing local government to use its procurement powers as a means of growing the social enterprise sector. The 2008 White Paper on local government, Communities in control: real people, real power, includes the following:

Communities and Local Government [the department responsible for local government] wants communities to benefit fully from the skills, knowledge and expertise of social enterprises. A new Social Enterprise Unit is in the process of being established that will champion the role of social enterprise models in delivering Communities and Local Government's strategic objectives, by recognising their contribution in areas such as housing, regeneration and creating empowered and cohesive communities. Supporting social enterprises to empower communities and local residents is a key theme of the new Empowerment Fund, details of which are published alongside this White Paper.

In addition we will encourage local authorities to ensure that social enterprises are able to compete fairly for contracts. Social enterprises often offer good value for money and innovation. However, they also often experience difficulties in breaking into the local government market. Local authorities should think about their role in supporting and promoting social enterprises through procurement. For example, contracts should be advertised in forums social enterprises access and contracts could be broken down into smaller sections making it easier for social enterprises to bid for them. (Communities in control 2008, 10) [Emphases in the original.]

In Melbourne, Australia, Moreland Energy Foundation Ltd (MEFL) provides another interesting example of a social enterprise, especially relevant for councils which are interested in promoting energy efficiency. MEFL is an independent not-for-profit organization established by the Moreland City Council from the proceeds from compulsory privatisation in the 1990s of its municipal electricity undertaking, to help 
reduce greenhouse gas emissions across the municipality. ${ }^{3}$ Effectively, the city had made the decision that the promotion of energy efficiency was something it should support but that it was best done through an independent entity funded by the city, rather than through the council itself. MEFL works with households, businesses, schools and community groups helping to:

- reduce wasteful energy use

- save money on power bills

- make buildings more comfortable to live and work in all year round.

This work is done through:

- advice, training, consultancy services and advocacy work

- cheap and easy energy-saving tips, resource guides and information kits

- a 'Five Star Home Renovator's Service'

- detailed energy audits and recommendations.

MEFL also works on climate change and energy initiatives with other councils in its part of the metropolitan area. One of its recent initiatives, working with Darebin City Council, is Community Power, a partnership with Origin Energy to supply green power (see www.communitypower.org).

The purpose of both these examples is to illustrate that the potential for local government procurement activity to support the establishment and growth of quite innovative organisations is very real. In a wider sense, both also illustrate the point that creative thinking by local authorities can unlock very significant potential within their communities which might otherwise go untapped.

\section{New Zealand}

This part of the paper will look at three separate initiatives currently in place or under development which have the potential to radically reshape the way we think about the role of local government. They are rates postponement, community banking and community management of council assets.

\footnotetext{
${ }^{3}$ Moreland municipality is on the fringe of the inner-city of Melbourne.
} 


\section{Rates postponement}

The legislative changes which made promoting community well-being the purpose of New Zealand local government were part of a wider rewrite of local government legislation which amongst other things gave local authorities greater discretion in the way they undertook their activities, but also required greater accountability, including prospective accountability. One major objective of the rewrite was to streamline legislation. Crucially as this turned out, it included changing two important elements of rating law:

- The existing power to impose a special rate over part of the district, intended primarily to meet the cost of debt servicing for a loan raised to provide expenditure benefiting only part of the district, was replaced by the power to impose a targeted rate on the whole of the district, part of the district or even a single property and for a range of matters including "The provision or availability to the land of a service provided by, or on behalf of, the local authority."

- Existing provisions enabling local authorities to postpone the payment of residential rates on hardship grounds were replaced with broader provisions which in effect now allow local authorities to adopt whatever postponement policy or policies they wish so long as they do so through a defined consultative process (the council's Long-Term Council Community Plan).

The introduction of these legislative changes coincided with the beginnings of the major residential property boom which much of the world experienced in the lead up to the global financial crisis. In New Zealand, this had a particular impact on certain categories of ratepayer - those who owned residential property in prime locations such as coastal or other waterfront, and high-quality rural lifestyle areas. New Zealand local authorities revalue properties for rating purposes at least once every three years and quite often annually. Councils with significant areas of premium properties within their districts found that the rateable values of different types of residential properties were changing by vastly different proportions. As an extreme example, one council in one revaluation recorded changes ranging from $-10 \%$ to $+300 \%$. A complicating factor was that many of these premium properties were owned by retired people on low fixed incomes - quite commonly living in the beach house which they had bought some 30 or 40 years ago and whose value had now risen dramatically because of increasing land prices. This presented councils with a very real challenge. There was no real case for remitting rates, 
or trying to set rates on an age-related basis (which was not possible under the legislation anyway), but it was very clear that a number of older people were going to be facing genuine difficulty - in the jargon, they were 'asset rich but income poor'. For some of these authorities, addressing this was not just a matter of political pressure from disgruntled ratepayers, but also an obvious community well-being issue. They combined to develop best practice methodologies for offering older people the opportunity of postponing their rates indefinitely on a basis designed to be cost neutral between ratepayers who took advantage of rates postponement, and ratepayers generally.

So far, this sat reasonably well within conventional local government activity. The rates postponement arrangements were far more user-friendly than the previous hardship provisions, but entirely consistent with the way that local authorities had managed rating over many years (including the fact that they enjoy the benefit of a statutory first charge over the land to secure the unpaid rates). The next step was logical, apparently incremental, but in practice a fundamental shift in the role of local government. The chief executive, who at the time chaired the joint committee which oversaw the operation of the rates postponement group, began reflecting on the relationship between rates postponement and community well-being. He was very aware of the fact that a number of the older people within his district lived in homes which were not well insulated and were also poorly heated. The result was quite serious health problems particularly during winter, especially as many older people believed they could not afford the costs of properly heating their homes. He raised the question of whether rates postponement could be used as a mechanism for enabling older people to better manage the energy related aspects of their quality of life. At the same time the government's Energy Efficiency and Conservation Authority (EECA) was looking to extend the uptake of residential retrofits, primarily for energy efficiency purposes but also very much in recognition of the resultant health benefits. The two came together. EECA had developed a new subsidy program to encourage home insulation and heating upgrades. It would either give the homeowner a grant if the homeowner was in a position to fund the capital cost, or provide an interest-rate subsidy if the homeowner needed to borrow. It recognised that for older people on low fixed incomes, even an interest-rate subsidy might not be sufficient as they were likely to have difficulty managing the capital repayments. Accordingly it wanted an option which would allow older people to draw down the equity in their homes. 
In New Zealand, as in Australia, the private sector in recent years has developed various forms of home equity release. However, as experience with these options has grown, so has the resistance of older people to their use. There is a growing sense that they are both very costly, and carry with them unacceptable risks. EECA was told quite firmly by older persons' advocates that a private sector option would not be acceptable. Instead, EECA has worked with local government to develop a rates-based solution. This involves the local authority adopting a policy of encouraging home retrofits, levying a targeted rate to cover the home owner's contribution to the cost of individual retrofits, and then postponing that rate. It is seen by older people themselves as an extremely cost-effective and fair way of facilitating home equity release. It is clear, in looking at the way this would work, that local authorities have a very considerable comparative advantage for reasons including:

- In jurisdictions where local authorities levy some form of rate or property tax they will have a comprehensive record of every residential property and its ownership. This in itself is a unique resource which would be extraordinarily expensive to replicate.

- An already established system for levying individual properties and where appropriate postponing any levy.

- A very simple means of establishing priority to protect any outstanding debt balance.

- The ability to exactly match the amount of the targeted rate to the cost of the specific service.

- An acceptance that their involvement in this type of activity is a ratepayer service, not a for-profit venture. In New Zealand at least, the statutory framework prevents councils from making a surplus from rates postponement (the legislation permits cost recovery but no more).

The legislative framework which is enabling home equity release is general in its terms, and not specific to energy retrofits. As noted above, a New Zealand local authority can impose a targeted rate for "The provision or availability to the land of a service provided by, or on behalf of, the local authority." Informal discussions are currently under way on how this approach could be extended to other services which might improve the quality of life of older people. Possible examples include home maintenance generally, personal services which would support ageing in place, and possibly discretionary health care (recognising that the likely health needs of our ageing populations are likely to far 
outstrip the funding capability of governments). The most interesting possibility is the idea of a debit card which an older person could use to pay for a range of services from approved providers (important to ensure that older persons are getting both good service and value for money). The older person could either pay some or all of the outstanding balance as it falls due, or have payment default to a targeted rate which was then postponed. One issue for local authorities, if this use of the rating system becomes more common, is who ensures the quality and value for money aspects of any service. Under the arrangement with EECA, it takes responsibility for approving installers, and monitoring their performance so that the local authority has no need to be concerned about these aspects. Expansion to a wider range of services would almost certainly require the establishment of some arm's-length arrangement to be responsible for specifying service requirements, approving providers, and monitoring service quality and value for money.

Another issue is what this means for local authority balance sheets. Postponed rates are a very secure financial asset. The risk of loss in any individual case is minimal. However, they are hardly liquid and the average rates postponement arrangement is likely to remain on the local authority's books for anything up to 10,15 or more years. It is recognised that, as the use of rates postponement grows, this question will need to be addressed. It is seen, however, as more in the nature of a technical issue than a real threat to local authority balance-sheet capability. The likeliest medium-term solution is an option or options which will see local government's comparative advantage (database, collection capability, community base etc) used as the means of delivering home equity release to support a wide range of services, but with the funding arrangements being held elsewhere. The key policy issue here is whether this is the type of activity which local governments should be engaged with. What will increasingly become the short answer when this issue is discussed is: why would you want to leave this option out of the range of mechanisms which will be needed to ensure that older people can afford a reasonable quality of life, without bankrupting the taxpayer?

\section{Community banking}

There is an increasing awareness that one significant issue in dealing with social exclusion is access to financial services. This has been recognised, for example, in the 
work of the Melbourne Institute of Applied Economic and Social Research. ${ }^{4}$ This also has been a concern for some local authorities within New Zealand. It has resulted in them exploring the possibility of a New Zealand equivalent of the Bendigo Bank's community banking initiative in Australia. ${ }^{5}$ In contrast, however, to the Bendigo approach, the New Zealand initiative will involve local government as a facilitator working in partnership with a registered bank. In a number of cases this will extend to providing premises on a co-location approach with local authority service centres (expected to provide cost benefits both for the banking entity and for the local authority itself). The purpose is not to have local government get into the banking business, so much as to facilitate a new and potentially valuable community resource. After looking closely at the Bendigo model, the New Zealand local authorities involved with this initiative have concluded that community banking offers benefits including:

- A stronger focus on the needs of the local community, including improved access to banking services.

- Over time, a new source of funding for community activity.

- An important new community capability. As an example, there is a very real possibility that community bank branches, once established, could play a role in ensuring quality of service and value for money for rates postponement funded services - and the banking partner could be the provider of the debit card arrangement and otherwise play an important funding role.

There has been some critical comment suggesting that local authorities have no business getting into banking. The local government response has been first that they are not getting into banking - branches will be community owned, not local government owned. Individual local authorities will be involved as facilitators, with some sharing of facilities and potentially staff with the principal objective of reducing costs for both parties.

\footnotetext{
${ }^{4}$ See Rosanna Scutella, Roger Wilkins and Michael Horn, 'Measuring Poverty and Social Exclusion in Australia: A Proposed Multidimensional Framework for Identifying Socio-Economic Disadvantage,' Working paper 4/09, Melbourne Institute of Applied Economic and Social Research, available at: Hhttp://ideas.repec.org/p/iae/iaewps/wp2009n04.html

5 Community banking operates as a franchise. Bendigo Bank is the franchisor, provides all of the banking products and services, and is responsible for quality assurance and oversight of individual outlets. Outlets themselves are owned by stand-alone companies with shareholding spread quite widely through their individual communities. Franchise profits are split between shareholders, reserves to build up capital, and community distributions. In some instances, individual community bank branches are now capable of distributing in excess of \$A100,000 annually. Community bank boards also act as a new and important source of community capability, with individual bank branches increasingly taking the lead in management of community projects which require the type of capability normally only found in commercial organisations.
} 
Perhaps more importantly, local government has also emphasised that financial services are just as much a part of community infrastructure as water, roading or sewerage, or for that matter broadband. It is extremely difficult to understand why local authorities should be seen as natural facilitators of broadband development but should not be involved in the development of improved access to financial services.

\section{Community management of council assets}

Most councils hold very extensive assets, especially in the form of land, much of which may be relatively under-utilised but which is nonetheless retained in council ownership quite legitimately because it is seen as being a community resource which should be held for the community's benefit. Especially as council funding comes under increasing pressure, there is a strong argument that all councils should do what they can to get the maximum benefit from the assets they hold. Often this may involve quite significant development activity. Few councils have the commercial skills and experience to compete with the private sector in development. Those which are successful in doing so are often, in effect, exploiting a relative monopoly position. The immediate option of 'if you don't have the skills acquire them' is not really feasible. First, skills are required at both the management and governance levels. It is simply not sufficient to appoint experienced development staff but have them reporting to elected members who do not have the skills, experience and capability required for the governance of substantial development activity. Secondly, it is extremely difficult both to appoint adequately qualified people, and to ensure that the mix of elected members includes the appropriate skills: this is not how democracy always works. This will be the case even if the community has within it people with the requisite skills who are interested in helping the community develop its asset base. One reason is that people with high level commercial skills will often find it frustrating working within a council environment either as management, or in a governance role as elected members.

One New Zealand local authority has recently taken an initiative to deal with this problem. It owns substantial land resources which are likely to increase significantly in value both because of the council's own prime coastal situation and because of some major developments taking place within the district. It very much wants to ensure that the community as a whole benefits from the development it is expecting, rather than a few, almost certainly out of town, developers. It also has within its business community people with very good commercial track records who are prepared to put time and effort 
into helping the council add value to its assets. What the council has done is to establish an incorporated charitable trust with a brief to create, manage, and distribute community wealth. The trustees are selected on a 'fit for purpose' basis. The council and the trust are together evaluating the council's portfolio. Land selected for development will be made available to the trust under a development licence designed to ensure that, if development does not proceed, the land reverts to the council. It is an exciting way of combining private sector skills with community objectives, ensuring that resources built up in the community over the years are not lost simply because the council itself lacks the skill base required. It also fits very well with the emerging emphasis on using council procurement policy as a means of developing or enabling community capability.

\section{Conclusion}

Each of these three initiatives is still very much work in progress. Each represents a significant development in the role of local government, but also can be seen as sitting squarely within the broad principles on which local government is based. Historically local government's principal role has been acting on behalf of the collective community to deliver services which will lead to improved outcomes for the area. These initiatives are entirely consistent with that role. The primary difference is that over the years the way we think about the role of local government seems to have shifted from seeing local government as a community-based resource for developing and delivering solutions on matters that require a collective approach, to seeing it as somehow fixed in a point of time in terms of the services it delivers (a view implicit in calls that local government should stick to its 'core business').

The possibility of private alternatives has always existed with virtually all main local government services. Toll roads, for example, were common in England in the 18th century. Libraries have always had their private sector equivalents. But as communities we use local government as an option for a number of reasons including:

- The efficiency advantages which come from minimising free-rider and transaction cost problems in delivering services where a significant majority but not all of the public want access.

- Often, a belief that there are public or merit good issues which would be disregarded by private sector providers.

- The sense that 'community' matters and that there will always be issues which need to be resolved at the community level, but will not be adequately handled if 
left solely to the private sector or for that matter a higher tier of government - the challenges of an ageing population offer a current high-profile example.

Thus the New Zealand examples outlined are not a radical departure from the 'core business' of local government. Rather they are an application of long held principles to new needs and opportunities.

\section{References:}

Communities and Local Government 2008, Communities in control: Real people, Real power, White Paper, Communities and Local Government (UK).

$<$ http://www.communities.gov.uk/communities/communityempowerment/communitiesincontrol>.

Finn, J-G. 2008, Building Stronger Local Governments and Regions: An Action Plan for the Future of Local Governance in New Brunswick, Report of the Commissioner on the Future of Local Governance, Government of New Brunswick, Canada. $<\underline{\text { http://www.gnb.ca/cnb/promos/flg/mainreport-e.asp }>\text {. }}$

Local Government Rates Inquiry Panel 2007, Funding Local Government, Report of the Local Government Rates Inquiry, Local Government Rates Inquiry. $<$ http://www.dia.govt.nz/diawebsite.nsf/wpg_URL/Agency-Independent-Inquiry-intoLocal-Government-Rates-Rates-Inquiry-Reports?OpenDocument>.

Lowery, D. 2000, 'A Transactions Costs Model of Metropolitan Governance: Allocation Versus Redistribution in Urban America', Journal of Public Administration Research and Theory, vol. 10, no. 1, pp. 49-79.

McKinlay Douglas limited 2006, Local Government Structure and Efficiency, Local Government New Zealand. $<$ http://www.lgnz.co.nz/library/publications/download-docs.html $>$.

New Zealand Local Government Act 2002.

$<$ http://www.legislation.govt.nz/act/public/2002/0084/latest/DLM170873.html>.

Royal Commission on Auckland Governance, Submissions.

$<$ http://www.nzbr.org.nz/submissions.asp?DocType $=$ Submission\&offset $=10>$.

Scutella, R., Wilkins, R. and Horn, M. 2009, Measuring Poverty and Social Exclusion in Australia: A Proposed Multidimensional Framework for Identifying Socio-Economic Disadvantage, Working paper 4/09, Melbourne Institute of Applied Economic and Social Research. $<$ http://ideas.repec.org/p/iae/iaewps/wp2009n04.html $>$. 